GMR

\title{
An optimized protocol for DNA extraction in plants with a high content of secondary metabolites, based on leaves of Mimosa tenuiflora (Willd.) Poir. (Leguminosae)
}

\author{
S.R. Arruda ${ }^{1}$, D.G. Pereira ${ }^{2}$, M.M. Silva-Castro ${ }^{3}$, M.G. Brito ${ }^{3}$ and \\ A.M. Waldschmidt ${ }^{1}$ \\ ${ }^{1}$ Programa de Pós-Graduação em Genética, \\ Biodiversidade e Conservação, Departamento de Ciências Biológicas, \\ Universidade Estadual do Sudoeste da Bahia, Jequié, BA, Brasil \\ ${ }^{2}$ Departamento de Química e Exatas, \\ Universidade Estadual do Sudoeste da Bahia, Jequié, BA, Brasil \\ ${ }^{3}$ Departamento de Ciências Biológicas, \\ Universidade Estadual do Sudoeste da Bahia, Jequié, BA, Brasil \\ Corresponding author: M.G. Brito \\ E-mail: matheusgalvao07@gmail.com
}

Genet. Mol. Res. 16 (3): gmr16039063

Received August 9, 2016

Accepted April 27, 2017

Published July 6, 2017

DOI http://dx.doi.org/10.4238/gmr16039063

Copyright (C) 2017 The Authors. This is an open-access article distributed under the terms of the Creative Commons Attribution ShareAlike (CC BY-SA) 4.0 License.

\begin{abstract}
Some species are characterized by a high content of tannins, alkaloids, and phenols in their leaves. These secondary metabolites are released during DNA extraction and might hinder molecular studies based on PCR (polymerase chain reaction). To provide an efficient method to extract DNA, Mimosa tenuiflora, an important leguminous plant from Brazilian semiarid region used in popular medicine and as a source of fuelwood or forage, was used. Eight procedures previously reported for plants were tested and adapted from leaf tissues of $M$. tenuiflora stored at $-20^{\circ} \mathrm{C}$. The optimized procedure in this study encompassed the utilization of phenol during
\end{abstract}

Genetics and Molecular Research 16 (3): gmr16039063 
deproteinization, increased concentrations of cetyltrimethylammonium bromide and sodium chloride, and a shorter period and lower temperature of incubation concerning other methods. The extracted DNA did not present degradation, and amplification via PCR was successful using ISSR, trnL, ITS, and ETS primers. Besides M. tenuiflora, this procedure was also tested and proved to be efficient in genetic studies of other plant species.

Key words: Mimosoideae; Molecular marker; Genetic diversity; Tannins; Phenols

\section{INTRODUCTION}

During DNA extraction for molecular studies in plants, the high content of tannins, polysaccharides, and polyphenols might determine oxidation and degradation of DNA samples, besides inhibiting the activity of Taq DNA polymerase, causing polymerase chain reaction (PCR) to fail (Ferreira and Grattapaglia, 1998). The polysaccharides usually settle along with DNA resulting in a high viscous solution (Baratto and Megiolaro, 2012), while polyphenols in contact with DNA become oxidant, being observed a dark pellet after extraction of nucleic acids, thus jeopardizing both the amount and the quality of extract DNA (Fang et al., 1992; Sharma et al, 2002).

Nowadays, a high number of molecular techniques to detect polymorphisms in DNA sequences are available, such as ISSR (inter-simple sequence repeat), RFLP (restriction fragment length polymorphism), AFLP (amplified fragment length polymorphism), SSR (simple sequence repeats), SNP (single nucleotide polymorphism), ITS (internal transcribed spacer), and ETS (external transcribed spacer). These methods are useful in population, phylogeographic, phylogenetic, and molecular taxonomic studies of plants besides genetic improvement of crops (Wilson and Walker, 2010). In spite of their distinct approaches, these methods invariably demand a high number and quality of DNA samples, being dependent on efficient and fast procedures for DNA extraction (Porebski et al., 1999).

Even though several protocols of DNA extraction have been reported, their efficiency was insufficient to allow molecular analyses in some plant species such as Mimosa tenuiflora. Probably, such inefficiency is related to their high content of secondary metabolites (e.g., tannins) in leaves, commonly used as the source of DNA samples in genomic studies of plants (Sika et al., 2015).

M. tenuiflora (Willd.) Poir. (known as jurema-preta in Brazil) is a perennial leguminous tree belonging to the family Mimosoideae (Queiroz, 2009). The wood of this species is highly used in fuel production and for making posts, bridges, furniture, and fences (Maia, 2004). A tea made of bark pieces has also been used in popular medicine for treating wounds, burns, and acne since it presents antimicrobial, analgesic, and astringent effects (de Albuquerque et al., 2007). Both bark and stem induce psychoactive effects related to the presence of the alkaloid N,N-dimethyltryptamine (Souza et al., 2008). Because of these effects, this plant has been considered sacred by some Native tribes from Brazil semiarid region that traditionally prepared the "jurema wine" from bark pieces to be used in witch doctor rituals as well as in Afro-Brazilian cults (de Albuquerque et al., 2007).

This species also presents high contents of tannins (Barbehenn and Peter Constabel, 2011; Calegari et al., 2016), a group of secondary metabolites that act as a chemical defense

Genetics and Molecular Research 16 (3): gmr16039063 
of plants against herbivory (Santamaria, 1999). Tannins are also able to settle proteins from animal skin, being extracted and highly used by local populations in leather production.

In this regard, the goal of the present study was to optimize a protocol for genomic DNA extraction for M. tenuiflora at low costs, without the utilization of expensive DNA extraction kits or liquid nitrogen, that could remove secondary metabolites, mainly tannins, and test its efficiency in analyses with PCR-based markers like ISSR and amplification of nuclear (ITS, ETS) and plastid $(\operatorname{trn} \mathrm{L})$ sequences. This procedure was also tested in other plant species characterized by high amounts of metabolites such as Syagrus harleyi Glassman, Syagrus coronata (Mart.) Becc. (Arecaceae), and Attalea sp Kunth.

\section{MATERIAL AND METHODS}

\section{Biological material}

The experiments of DNA extraction were carried out using leaves of three individuals of $M$. tenuiflora collected in the municipality of Jequié, a State of Bahia, Northeastern Brazil (13 $51^{\circ} 51^{\prime \prime S}$, $40^{\circ} 04^{\prime} 54^{\prime \prime} \mathrm{W}, 216 \mathrm{~m}$ above sea level). The leaf tissues were stored $-20^{\circ} \mathrm{C}$ in the Laboratory of Molecular Genetics at Universidade Estadual do Sudoeste da Bahia (UESB) in Jequié.

Seven previously reported protocols for isolation of DNA were tested, besides an optimized method described in the present study. Each protocol was performed in triplicates as described in Table S1. To test the applicability of the optimized protocol in other plant species, this procedure was tested using leaves of Syagrus coronata, Syagrus harleyi, and Attalea sp.

To test the efficiency of extracted DNA from the optimized protocol, we performed amplification of DNA sequences via PCR. The ISSR markers were amplified from 15 DNA samples of $M$. tenuiflora while the trnL, ITS, and ETS regions were amplified from four individuals of the same species.

\section{Quantitative and qualitative analysis of extracted DNA}

The number and the quality of DNA samples were estimated from the absorbance values at wavelengths of 230, 260, and $280 \mathrm{~nm}$ using an L-Quant spectrophotometer. The DNA purity was determined according to the $\mathrm{A}_{260} / \mathrm{A}_{280}$ absorbance ratio. The contamination by polysaccharides was calculated using the $\mathrm{A}_{260} / \mathrm{A}_{230}$ ratio (Barbehenn and Peter Constabel, 2011).

After quantifying the values obtained in DNA samples from each protocol, a variance analysis was carried out and mean values were compared by the Tukey test (significance level of 5\%), using the SAS software (SAS Institute, 2003) and Assistant v. 7.1 (Silva and Azevedo, 2002).

\section{Amplification of ISSR markers}

A total of 15 individuals of $M$. tenuiflora from Jequié were used in ISSR-PCR tests. The amplification via PCR was carried out in an MG108+ thermocycler using the primer UBC-864 (University of British Columbia). Each reaction comprised $10 \mathrm{mM}$ Tris-HCl, $\mathrm{pH}$ 8.3, $2.5 \mathrm{mM} \mathrm{MgCl}_{2}, 1 \mathrm{mM}$ dNTP mix, $0.2 \mathrm{M}$ primer, $5 \mathrm{U}$ Taq DNA polymerase (Biotools), and $30 \mathrm{ng}$ template DNA to a final volume of $25 \mu \mathrm{L}$. The amplification conditions were: an initial denaturation step at $94^{\circ} \mathrm{C}$ for 3 min followed by 39 cycles at $92^{\circ} \mathrm{C}$ for $1 \mathrm{~min}, 53^{\circ} \mathrm{C}$ for $2 \mathrm{~min}$ and $72^{\circ} \mathrm{C}$ for $2 \mathrm{~min}$, plus a final extension step at $72^{\circ} \mathrm{C}$ for $7 \mathrm{~min}$.

Genetics and Molecular Research 16 (3): gmr16039063 
After electrophoresis of the amplified products on 1.2\% agarose geland stained with GelRed, the bands were visualized and photo-documented using an L-pix UV-transilluminator.

\section{Amplification of ITS, ETS, and trnL sequences}

Four samples of $M$. tenuiflora collected in Jequié were used to amplify specific DNA sequences using the primers: 5'-AGCAATTCATGGTCCGGTGAAGTGTTCG-3' and 5'-TAGAATTCCCCGGTTCGCTCGCCGTTAC-3' (ITS); 5'-ATAGAGCGCGTGAGTGGT G-3' and 5'-GAGACAAGCATATGACTACAG-3' (ETS); and 5'-CGAAATCGGTAGACGCT ACG-3' and 5'-AATTGAACTGGTGACACGAG-3' $\operatorname{trn} \mathrm{L}$ ). Each reaction comprised $25 \mu \mathrm{L}$ with $10 \mathrm{mM}$ Tris- $\mathrm{HCl}, \mathrm{pH} 8.3,1.5 \mathrm{mM} \mathrm{MgCl}, 1 \mathrm{mM}$ dNTP mix, $0.5 \mathrm{M}$ of each primer, $5 \mathrm{U}$ Taq DNA polymerase (Biotools), and 20 ng template DNA.

The PCR was carried out in an MG108+ thermocycler using the following conditions for $\operatorname{trnL}$ sequences: $94^{\circ} \mathrm{C}$ for $1 \mathrm{~min}, 30$ cycles at $94^{\circ} \mathrm{C}$ for $1 \mathrm{~min}$ and $72^{\circ} \mathrm{C}$ for $1 \mathrm{~min}$, plus a final extension at $72^{\circ} \mathrm{C}$ for $7 \mathrm{~min}$. In the case of ITS, the PCR conditions were similar except for the annealing temperature $\left(55^{\circ} \mathrm{C}\right)$. The ETS sequences were amplified following $92^{\circ} \mathrm{C}$ for $2 \mathrm{~min}, 30 \mathrm{~s}$ of denaturation at $94^{\circ} \mathrm{C}, 60 \mathrm{~s}$ of annealing at $55^{\circ} \mathrm{C}$, and $60 \mathrm{~s}$ at $72^{\circ} \mathrm{C}$, totaling 30 cycles, besides a final extension at $72^{\circ} \mathrm{C}$ for $5 \mathrm{~min}$. The amplified sequences were submitted to electrophoresis on 1.5\% agarose gel, employing GelRed and bromophenol (2:1), being visualized and photo-documented using an L-pix UV-transilluminator.

\section{RESULTS}

The mean concentration and purity of DNA samples extracted from leaves of $M$. tenuiflora based on the eight procedures tested are presented in Table 1, along with the values of coefficient of variation (CV) and results of the Tukey test using 5\% of significance.

Table 1. Quantification and quality analysis of extracted DNAs from the eight tested procedures based on leaf
tissues of Mimosa tenuiflora according to their absorbance $\left(\mathrm{A}_{230}, \mathrm{~A}_{260}\right.$, and $\left.\mathrm{A}_{280 \mathrm{~nm}}\right)$, concentration, and visual aspect.
\begin{tabular}{l|c|c|c|l}
\hline Protocol & Mean of $\mathrm{A}_{260 / 280}$ ratio $\pm \mathrm{SD}$ & Mean of $\mathrm{A}_{260 / 230}$ ratio $\pm \mathrm{SD}$ & Mean of concentration $(\mathrm{ng} / \mu \mathrm{L}) \pm \mathrm{SD}$ & Color/Viscosity \\
\hline Faleiro et al. (2003) & $1.45^{\mathrm{ab}} \pm 0.08$ & $1.40^{\mathrm{de}} \pm 0.32$ & $155^{\mathrm{b}} \pm 1.00$ & Dark/Non-viscous \\
\hline Bonato et al. (2004) & $1.46^{\mathrm{ab}} \pm 0.08$ & $1.54^{\mathrm{de}} \pm 0.29$ & $859^{\mathrm{a}} \pm 29.59$ & Dark/viscous \\
\hline Murray and Thompson (1980) & $1.61^{\mathrm{ab}} \pm 0.05$ & $1.37^{\mathrm{de}} \pm 0.32$ & $480^{\mathrm{ab}} \pm 3.60$ & Dark/Non-viscous \\
\hline Roy et al. (1992) & $1.65^{\mathrm{ab}} \pm 0.04$ & $1.59^{\mathrm{de}} \pm 0.17$ & $234^{\mathrm{ab}} \pm 12.50$ & Dark/Non-viscous \\
\hline Doyle and Doyle (1987) & $1.54^{\mathrm{ab}} \pm 0.05$ & $1.54^{\mathrm{de}} \pm 0.08$ & $234^{\mathrm{ab}} \pm 11.24$ & Dark/viscous \\
\hline Haberer et al. (1996) & $1.53^{\mathrm{ab}} \pm 0.01$ & $1.25^{\mathrm{d}} \pm 0.03$ & $415^{\mathrm{ab}} \pm 14.15$ & Dark/viscous \\
\hline Promega kit & $0.93^{\mathrm{a}} \pm 0.12$ & $1.19^{\mathrm{f}} \pm 0.05$ & $189^{\mathrm{b}} \pm 1.00$ & Dark/viscous \\
\hline Optimized protocol & $1.83^{\mathrm{c}} \pm 0.03$ & $2.05^{\mathrm{d}} \pm 0.03$ & $399^{\mathrm{ab}} \pm 4.51$ & Clear/Non-viscous \\
\hline CV (\%)** & 17.13 & 18.38 & 52.32 & - \\
\hline
\end{tabular}

Mean values followed by the same letter were not statistically different according to the Tukey test at $5 \%$ probability. $\mathrm{SD}=$ standard deviation; $\mathrm{CV}=$ coefficient of variation.

The mean DNA concentration varied significantly according to each protocol (Table 1). The lowest concentration of DNA was obtained using the procedure described by Faleiro et al. (2003). On the other hand, the method reported by Bonato et al. (2004) yielded the highest DNA concentration $(859 \mathrm{ng} / \mathrm{mL})$ but also a high contamination by polysaccharides and polyphenols, as observed by the values of absorbance ratio $\mathrm{A}_{260} / \mathrm{A}_{280}(1.46)$ and $\mathrm{A}_{260} /$ $\mathrm{A}_{230}$ (1.54). Similarly, other procedures like Murray and Thompson (1980) and Promega kit (Wizard ${ }^{\circledR}$ Genomic DNA Purification and available at [http://www.promega.com.br/]) resulted

Genetics and Molecular Research 16 (3): gmr16039063 
in DNAs contaminated by proteins, according to the $\mathrm{A}_{260} / \mathrm{A}_{280}$ ratio (Table 1). Therefore, all procedures except the optimized method herein described, resulted in low-quality DNA since the absorbance values in $\mathrm{A}_{260} / \mathrm{A}_{230}$ ratio were below the threshold (2.0-2.2) expected for pure DNA samples, free of secondary metabolites.

No significant difference was observed in quantitative analysis, except for the Promega kit. The optimized protocol was significantly superior to the Promega kit according to the Tukey test $(\mathrm{P}=0.05)$. The coefficient of variation ranged from $17.13 \%\left(\mathrm{~A}_{260} / \mathrm{A}_{280}\right.$ ratio $)$ to $52.32 \%$ (concentration), indicating that the precision of each method varied from good to regular. The qualitative variables (color and viscosity) determined by the aspect of pellets after DNA extraction have also varied, even though most of the protocols produced dark and viscous pellets. The procedure described by Doyle and Doyle (1987) was modified (optimized protocol), and it differed from the other procedures by i) the increased concentration of cetyltrimethylammonium bromide (CTAB) (from 1-2 to 3\%) and $\mathrm{NaCl}$ (from 2 to $2.5 \mathrm{M}$ ), ii) addition of phenol to the deproteinization process, iii) reduction of the incubation period (30-60 to $20 \mathrm{~min}$ ), and temperature $\left(65-70^{\circ}\right.$ to $\left.60^{\circ} \mathrm{C}\right)$, and iv) increased concentration of polyvinylpyrrolidone (PVP) (2\%) and $\beta$-mercaptoethanol (5\%).

The amplification tests using the DNA extracted according to the optimized protocol were successful using ISSR, $\operatorname{trn} \mathrm{L}$, ITS, and ETS primers (Figure 1A).
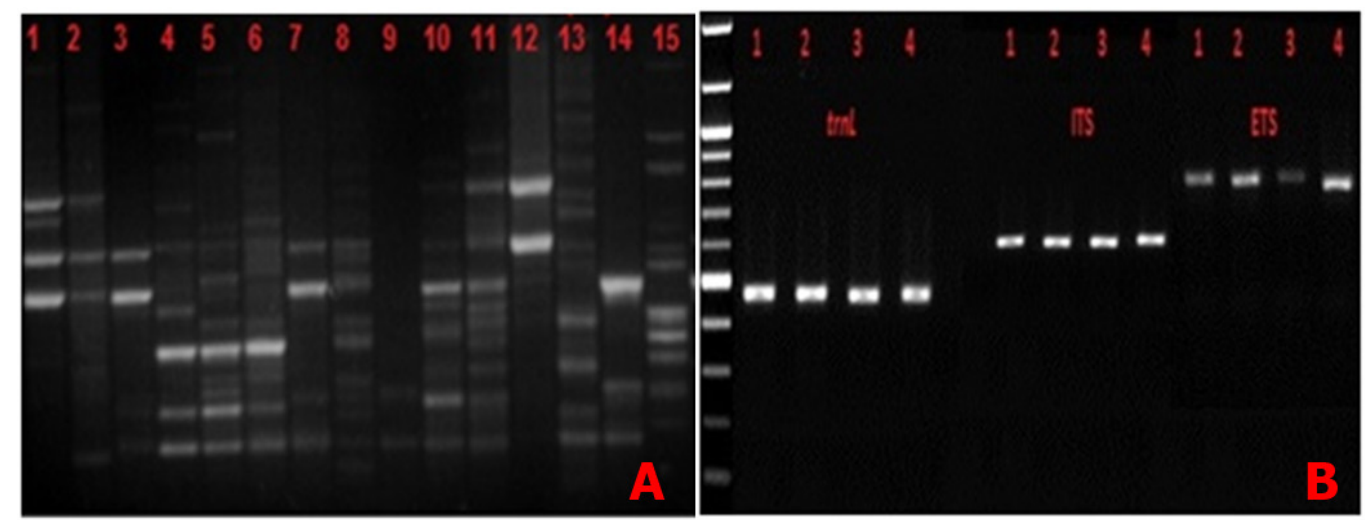

Figure 1. Amplification pattern of 15 DNA samples of Mimosa tenuiflora using the ISSR primer (UBC-864) (A), and DNA sequences $(\operatorname{trn} \mathrm{L}=\sim 350 \mathrm{bp}$, ITS $=\sim 500 \mathrm{bp}$, and $\mathrm{ETS}=700 \mathrm{bp}$ ) of four specimens of $M$. tenuiflora (B).

The optimized protocol was also effective to extract high-quality DNA in other plant species with high amounts of secondary metabolites (Table 2).

Table 2. Quantification and quality analysis of extracted DNAs from distinct plant species using the optimized protocol developed in the present study.

\begin{tabular}{l|c|c|c|l}
\hline Species & Mean of $\mathrm{A}_{260 / 280}$ ratio $\pm \mathrm{SD}$ & Mean of $\mathrm{A}_{260 / 230}$ ratio $\pm \mathrm{SD}$ & Concentration $(\mathrm{ng} / \mu \mathrm{L}) \mathrm{SD}$ & Color/Viscosity \\
\hline Syagrus coronata & $1.79 \pm 0.05$ & $1.89 \pm 0.08$ & $326 \pm 56.80$ & Clear/Non-viscous \\
\hline Syagrus harleyi & $1.80 \pm 0.09$ & $2.05 \pm 0.17$ & $256 \pm 19.14$ & Clear/Non-viscous \\
\hline Attalea $\mathrm{sp}$ & $1.77 \pm 0.03$ & $1.91 \pm 0.19$ & $150 \pm 30.05$ & Clear/Non-viscous \\
\hline
\end{tabular}

$\mathrm{SD}=$ standard deviation 


\section{DISCUSSION}

The obtaining of high quality and quantities of DNA is the first step to assure the efficiency of molecular studies in plants. In the case of species characterized by high contents of secondary metabolites, like M. tenuiflora, this procedure requires intensive testing and adaptation of different protocols. The optimized protocol presented in this study resulted in a mean DNA concentration of $399 \mathrm{ng} / \mu \mathrm{L}$ extracted from leaf samples of M. tenuiflora. Even though this value was on average lower than those obtained by other protocols (Murray and Thompson, 1980; Roy et al., 1992; Haberer et al., 1996; Bonato et al., 2004), the optimized method assured the extraction of pure DNA based on both quantitative $\left(\mathrm{A}_{260} / \mathrm{A}_{280}\right.$ and $\mathrm{A}_{260} \mathrm{I}$ $\mathrm{A}_{230}$ ratios) and qualitative (color and viscosity) parameters. The recommend values for the $\mathrm{A}_{260} / \mathrm{A}_{280}$ ratio should range from 1.8 to 2.0 , and the optimized protocol was the only method that results in absorbance values within this interval (mean of 1.83), thereby characterizing high-quality DNA samples. Higher values of absorbance ratios are evidence of contamination by phenols while lower values indicate the presence of proteins once proteins absorb light at a wavelength of $280 \mathrm{~nm}$ (Romano and Brasileiro, 1999). It is important to point out that the Promega kit is not specific to plant species with high quantities of secondary metabolites what could account for their lower efficiency in our experiments.

Likewise, except for the optimized protocol, all procedures were below the recommended values for the $\mathrm{A}_{260} / \mathrm{A}_{230}$ ratio (2.0-2.2) in pure DNA samples, free of contaminants and secondary metabolites. Even though the optimized protocol was not significantly different from the others when compared with this parameter in the Tukey test $(\mathrm{P}=0.05)$, the mean value obtained by this method (2.05) was the only one within the reference interval. In the case of the other protocols, a reprecipitation of DNA would be recommended before the utilization in molecular studies (Barbosa, 1998). Since both the composition and concentration of reagents can interfere with the quality and the quantity of extracted DNA (Borges et al., 2012), the optimized protocol was developed using a higher concentration of $\mathrm{CTAB}(3 \%)$ and $\mathrm{NaCl}(2.5 \mathrm{M})$. This modification allowed a more efficient elimination of polysaccharides once high levels of $\mathrm{CTAB}$ and $\mathrm{NaCl}$ determine a higher solubility of polysaccharides regarding DNA, thereby favoring their removal during washes in ethanol (Fang et al., 1992). The efficiency of increased $\mathrm{NaCl}$ levels to remove polysaccharides during DNA extraction was corroborated by studies with other plant species like Cymbopogon winterianus Jowitt, Pelargonium graveolens, and Taxus wallichiana Zucc (Khanuja et al., 1999; Lodhi et al., 2011). Furthermore, the presence of CTAB and $\mathrm{NaCl}$ form a complex with DNA samples that facilitate the settlement of nucleic acids.

On the other hand, polyphenols attach to DNA when the cell walls are broken down

during the maceration process, leading to irreversible oxidation of DNA and inhibition of restriction enzymes and DNA polymerases thus hindering PCR experiments (Couch and Fritz, 1990). To avoid the oxidative effect of polyphenols, the extraction buffer should contain anti-oxidant agents, such as PVP (polyvinylpyrrolidone), BSA (bovine serum albumin), or $\beta$-mercaptoethanol (Romano and Brasileiro, 1999). Some of the reported protocols tested in this study (Doyle and Doyle, 1987; Roy et al., 1992; Faleiro et al., 2003; Bonato et al., 2004) include these reagents in concentrations that range from 0.2 to $2 \% \beta$-mercaptoethanol and 1 to $2 \%$ PVP. In the optimized protocol, the concentration of $\beta$-mercaptoethanol was increased to $5 \%$, once a high concentration of this compound is important to reduce polyphenols during DNA extraction of tissues with a high content of secondary metabolites (Khanuja et al., 1999). Indeed, samples of DNA from mangrove leaves were characterized by contamination with

Genetics and Molecular Research 16 (3): gmr16039063 
polyphenols and polysaccharides, resulting in dark and sticky pellets after isolation (Sahu et al., 2012). To overcome this obstacle, the concentration of $\beta$-mercaptoethanol and PVP was increased from 2 to $5 \%$ and from 1 to $2 \%$, respectively, thus yielding clear and non-viscous pellets in extracted DNA samples.

Most procedures of DNA extraction incubate the samples at $65^{\circ}-70^{\circ} \mathrm{C}$ for 30 to 60 min. In the optimized protocol, both incubation period and temperature were reduced to 20 $\min$ and $60^{\circ} \mathrm{C}$, respectively. Moreover, the samples were homogenized by inverting the tubes each $10 \mathrm{~min}$. Using this procedure, the samples became clearer when compared to those incubated for longer periods at higher temperatures. The dark coloration of DNA samples suggests a putative oxidation by phenolic compounds (Reed, 1995). In fact, soluble tannins and other contaminants might attach DNA leading to irreversible oxidation at temperatures above $60^{\circ} \mathrm{C}$. Supporting this evidence, the utilization of lower temperatures were successful for the extraction of DNA from Broussonetia papyrifera (Moraceae) (Moncada et al., 2013).

The deproteinization process was accomplished using an organic solvent (phenol) along with chloroform and isoamyl alcohol, thereby leading to a more efficient denaturation of proteins besides inhibiting the activity of nucleases. The absorbance ratios $\left(\mathrm{A}_{260} / \mathrm{A}_{280}=1.8\right.$ and $\left.\mathrm{A}_{260} / \mathrm{A}_{230}=2.05\right)$ in the optimized protocol presented the recommended values to high-quality DNA samples (Sambrook and Russell, 2001). Differently from most methods, except that reported by Bonato et al. (2004), the protocol here presented used double deproteinization, using phenol:chloroform:isoamyl alcohol (25:24:1) followed by chloroform:isoamyl alcohol (24:1). In spite of reducing the concentration of DNA after extraction $(399 \mathrm{ng} / \mu \mathrm{L})$ (Table 1), the DNA samples obtained were characterized by their high purity. Similarly, in Arbutus unedo (Ericaceae), a species with a high content of polysaccharides, the more effective method of DNA extraction comprised the utilization of phenol:chloroform:isoamyl alcohol, resulting in contaminant-free DNA samples (Sá et al., 2011).

Besides $M$. tenuiflora, the optimized protocol was also successfully applied to isolate nucleic acids of Arecaceae plant species (Syagrus coronata, Syagrus harleyi, and Attalea sp). Therefore, the present methodology might be highly useful to molecular studies in other plant species rich in secondary metabolites.

To provide a reliable molecular analysis in plants, the conditions of DNA extraction should be tested once a standard protocol applicable to all plant species remains unavailable (Tacuatiá et al., 2012; Anuradha et al., 2013). Therefore, studies of genetic diversity, population structure, phylogenetics, and inheritance patterns of plants usually start from developing a suitable method of DNA extraction for a species or group of species (Akkurt, 2012; Li et al., 2013).

In this sense, the suitability of isolated DNA based on the optimized protocol to genetic analyses with molecular markers was evaluated. Using ISSR markers, several amplified fragments were clearly observed (Figure 1A), thus allowing further population studies. Moreover, specific sequences were successfully amplified from the DNA samples using the optimized protocol, comprising two nuclear (ITS and ETS of ribosomal genes) sequences and one plastid region $(\operatorname{trn} \mathrm{L})$ (Figure 1B). Variation in spacer sequences has been used to species identification, representing an informative marker in phylogenetic and phylogeographic studies (Lee and Taylor, 1992; Shaw et al., 2005). Therefore, the optimized protocol of DNA extraction resulted in high-quality DNA samples to be used in a variety of molecular studies of plants avoiding the utilization of specific DNA extraction kits, usually highly expensive for most Brazilian laboratories.

Genetics and Molecular Research 16 (3): gmr16039063 


\section{CONCLUSION}

In this study, we developed a new and efficient protocol for the isolation of genomic DNA from leaves of Mimosa tenuiflora that dismisses the utilization of specific DNA extraction kits. The DNA samples obtained were suitable for molecular analyses of M. tenuiflora such as population, phylogeographic, and phylogenetic studies.

Moreover, the present procedure has proven to be equally efficient to other plant species characterized by high content of polysaccharides and polyphenols.

\section{Conflicts of interest}

The authors declare no conflict of interest.

\section{ACKNOWLEDGMENTS}

The authors gratefully acknowledge the financial support of Universidade Estadual do Sudoeste da Bahia (UESB) and Programa de Formação de Recursos Humanos/Petrobras (\#PRHPB211).

\section{REFERENCES}

Akkurt M (2012). Comparison between modified DNA extraction protocols and commercial isolation kits in grapevine (Vitis vinifera L.). Genet. Mol. Res. 11: 2343-2351. https://doi.org/10.4238/2012.August.13.8

de Albuquerque UP, Muniz de Medeiros P, de Almeida AL, Monteiro JM, et al. (2007). Medicinal plants of the caatinga (semi-arid) vegetation of NE Brazil: a quantitative approach. J. Ethnopharmacol. 114: 325-354. https://doi. org/10.1016/j.jep.2007.08.017

Anuradha HJ, Vijayan K, Nair CV and Manjula V (2013). A novel and efficient protocol for the isolation of genomic DNA from mulberry (Morus L). Plant Sci. 25: 124-131.

Baratto C and Megiolaro MF (2012). Comparação de diferentes protocolos de extração de DNA de bactérias para utilização em RAPD-PCR. Unoesc. Ciênc. 3: 121-130.

Barbehenn RV and Peter Constabel C (2011). Tannins in plant-herbivore interactions. Phytochemistry 72: 1551-1565. https://doi.org/10.1016/j.phytochem.2011.01.040

Barbosa MM (1998). Quantificação e Controle da Qualidade do DNA Genômico. In: Marcadores Moleculares em Plantas (Milach S, eds.), UFRGS, Porto Alegre, 99-106.

Bonato ALV, Verzignassi JR, Resende RMS, Fernandes CD, et al. (2004). Extração de DNA genômico de Stylosanthes spp. Embrapa Gado de corte, Campo Grande.

Borges DB, Amorim MB, Waldschmidt AM, Mariano-Neto E, et al. (2012). Optimization of DNA extraction from fresh leaf tissues of Melanoxylon brauna (Fabaceae). Genet. Mol. Res. 11: 1586-1591. https://doi.org/10.4238/2012.May.22.8

Calegari L, Lopes PJG, Oliveira E, Gatto DA, et al. (2016). Quantificação de taninos nas cascas de jurema-preta e acácianegra. Pesq. Flor. Bras. 36: 61-69. https://doi.org/10.4336/2016.pfb.36.85.986

Couch JA and Fritz PJ (1990). Isolation of DNA from plants high in polyphenolics. Plant Mol. Biol. Report. 8: 8-12. https://doi.org/10.1007/BF02668875

Doyle JJ and Doyle JL (1987). Isolation of plant DNA from fresh tissue. Focus 12: 13-15.

Faleiro FG, Faleiro ASG, Cordeiro MCR and Karia CT (2003). Metodologia para Operacionalização a Extração de DNA de Espécies Nativas do Cerrado Visando Análises Moleculares. In: Comunicado Técnico, Embrapa, 92.

Fang G, Hammar S and Grumet R (1992). A quick and inexpensive method for removing polysaccharides from plant genomic DNA. Biotechniques 13: 52-54, 56.

Ferreira ME and Grattapaglia D (1998). Introdução ao Uso de Marcadores Moleculares em Análise Genética. Brasília, 1: 121-123.

Haberer G, Fischer TC and Torres-Ruiz RA (1996). Mapping of the nucleolus organizer region on chromosome 4 in Arabidopsis thaliana. Mol. Gen. Genet. 250: 123-128.

Genetics and Molecular Research 16 (3): gmr16039063 
Khanuja SPS, Shasany AK, Darokar MP and Kumar S (1999). Rapid isolation of DNA from dry and fresh samples of plants producing large amounts of secondary metabolites and essential oils. Plant Mol. Biol. Report. 17: 1-7. https:// doi.org/10.1023/A:1007528101452

Lee SB and Taylor JW (1992). Phylogeny of five fungus-like protoctistan Phytophthora species, inferred from the internal transcribed spacers of ribosomal DNA. Mol. Biol. Evol. 9: 636-653.

Li HY, Li Z, Cai L, Shi W, et al. (2013). Analysis of genetic diversity of Ruthenia Medic (Medicago ruthenica (L.) Trautv.) in Inner Mongolia using ISSR and SSR markers. Genet. Resour. Crop Evol. 60: 1687-1694. https://doi.org/10.1007/ s10722-012-9950-3

Lodhi MA, Weeden YGN, Weeden NF and Reisch BI (2011). A simple and efficient method for DNA extraction from grapevine cultivars and Vitis species. Plant Mol. Biol. Report. 12: 6-13. https://doi.org/10.1007/BF02668658

Maia GN (2004). Caatinga: árvores e arbustos e suas utilidades. D\&Z Computação, São Paulo.

Moncada X, Payacán C, Arriaza F, Lobos S, et al. (2013). DNA extraction and amplification from contemporary Polynesian bark-cloth. PLoS One 8: e56549. https://doi.org/10.1371/journal.pone.0056549

Murray MG and Thompson WF (1980). Rapid isolation of high molecular weight plant DNA. Nucleic Acids Res. 8: 43214325. https://doi.org/10.1093/nar/8.19.4321

Porebski S, Bailey LG and Baum BR (1999). Modification of a CTAB DNA extraction protocol for plants containing high polysaccharide and polyphenol components. Plant Mol. Biol. Report. 15: 8-15. https://doi.org/10.1007/BF02772108

Queiroz LP (2009). Leguminosas da caatinga. Feira de Santana, Universidade Estadual de Feira de Santana, Bahia.

Reed JD (1995). Nutritional toxicology of tannins and related polyphenols in forage legumes. J. Anim. Sci. 73: 1516-1528. https://doi.org/10.2527/1995.7351516x

Romano E and Brasileiro ACM (1999). Extração de DNA de plantas: soluções para problemas comumente encontrados. Biotecnolog. Cienc. Desenvolv. 9: 40-43.

Roy A, Frascaria N, Mackay J and Bousquet J (1992). Segregating random amplified polymorphic DNAs (RAPDs) in Betula alleghaniensis. Theor. App. Gen. 85: 173-180.

Sá O, Pereira JA and Baptista P (2011). Optimization of DNA extraction for RAPD and ISSR analysis of Arbutus unedo L. Leaves. Int. J. Mol. Sci. 12: 4156-4164. https://doi.org/10.3390/ijms12064156

Sahu, SK, Thangaraj, M, Kathiresan, K (2012). DNA extraction protocol for plants with high levels of secondary metabolites and polysaccharides without using liquid nitrogen and phenol. Inter. Scho. Res. Net. 1-6.

Sambrook J and Russell DW (2001). Molecular Cloning. CSH Press.

Santamaria LM (1999). Interacción entre organismos: sistemas de defesa. Berckeley, Chimera Javeriana.

SAS Institute (2003). Statistical analysis system: user's guide. Version 9.1. Cary.

Sharma AD, Gill PK and Singh P (2002). DNA isolation from dry and fresh samples of polysaccharide-rich plants. Plant Mol. Biol. Report. 20: 415-415. https://doi.org/10.1007/BF02772129

Shaw J, Lickey EB, Beck JT, Farmer SB, et al. (2005). The tortoise and the hare II: relative utility of 21 noncoding chloroplast DNA sequences for phylogenetic analysis. Am. J. Bot. 92: 142-166. https://doi.org/10.3732/ajb.92.1.142

Sika KC, Kefela T, Adoukonou-Sagbadja H, Ahoton L, et al.. (2015). A simple and efficient genomic DNA extraction protocol for large scale genetic analyses of plant biological systems. Plant Gene 1: 43-45. https://doi.org/10.1016/j. plgene. 2015.03.001

Silva FASE and Azevedo CAV (2002). Versão do programa computacional Assistat para o sistema operacional Windows. Rev. Bras. Prod. Agroind. 4: 71-78. https://doi.org/10.15871/1517-8595/rbpa.v4n1p71-78

Souza RSO, Albuquerque UP, Monteiro JM and Amorim ELC (2008). Jurema-Preta (Mimosa tenuiflora [Willd.] Poir.): a Review of its Traditional Use, Phytochemistry and Pharmacology. Braz. Arch. Biol. Technol. 51: 937-947. https://doi. org/10.1590/S1516-89132008000500010

Tacuatiá LO, Eggers L, Kaltchuk-Santos E and Souza-Chies TT (2012). Population genetic structure of Sisyrinchium micranthum Cav. (Iridaceae) in Itapuã State Park, Southern Brazil. Genet. Mol. Biol. 35: 99-105. https://doi. org/10.1590/S1415-47572012005000012

Wilson K and Walker J (2010). Principles and Techniques of Biochemistry and Molecular Biology. Camb. Univ. Press, New York, 399-401.

\section{Supplementary material}

Table S1. Detailed steps of each procedure tested for DNA extraction of Mimosa tenuiflora.

Genetics and Molecular Research 16 (3): gmr16039063 